Portland State University

PDXScholar

Fall 6-21-2013

\title{
The Effect of Teacher-Identified Classroom Management
}

Monica Rose Root

Portland State University

Follow this and additional works at: https://pdxscholar.library.pdx.edu/open_access_etds

Part of the Educational Assessment, Evaluation, and Research Commons, and the Secondary Education and Teaching Commons

Let us know how access to this document benefits you.

\section{Recommended Citation}

Root, Monica Rose, "The Effect of Teacher-Identified Classroom Management" (2013). Dissertations and Theses. Paper 1544.

https://doi.org/10.15760/etd.1543

This Thesis is brought to you for free and open access. It has been accepted for inclusion in Dissertations and Theses by an authorized administrator of PDXScholar. Please contact us if we can make this document more accessible: pdxscholar@pdx.edu. 
The Effect of Teacher-Identified Classroom Management

by

Monica Rose Root

A thesis submitted in partial fulfillment of the requirements for the degree of

\author{
Master of Science \\ in \\ Special Education
}

Thesis Committee:

Sheldon Loman, Chair

Christopher Borgmeier

Randall De Pry

Portland State University

2013 
(C) 2013 Monica Rose Root 
Abstract

The framework of this study was monitoring classroom management strategies and student behaviors in the classroom, then providing strategies and feedback to increase effective classroom management and decrease problem student behaviors.

There were 15 evidence-based practices that were researched and used in the study. Specifically teachers were asked to focus on 5 of them. These practices were: using 5 positive feedback comments to 1 negative comment; having classroom rules and expectations that were posted, taught, practiced, consistent, and positively reinforced; using an attention getting cue that had been taught, practiced and positively reinforced; having continuous active supervision including moving and scanning; and managing minor problem behaviors positively, consistently and quickly.

Teachers filled out a self-assessment tool on how well they think they implemented these strategies in the classroom, and then received coaching sessions on how to use them more effectively in the classroom. These coaching sessions were given throughout the study as teachers had days where they needed positive reinforcement themselves.

The results of these coaching sessions and the use of the strategies are presented in this study. 
I'd like to give a special thanks to my husband, Rob, for always believing in me even when I was ready to quit. It's been a long, but exciting journey this year with a lot of big changes. I love you and am excited to meet our new addition to the family soon and begin the next chapter of our lives.

Big thanks to my advisor Sheldon Loman, without him this could not have happened. Thanks for being flexible with my ever-changing schedules; everything that could have happened to interfere has, and we are still here at the end. Thank you.

Thank you to all of my co-workers that let me be a fly on the wall in their classes and provide feedback. Also, to all of the girls who tried their best to ignore my presence in their classroom.

It has been an exciting journey and took everyone to get here. 


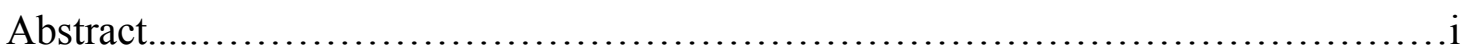

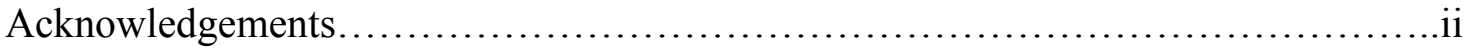

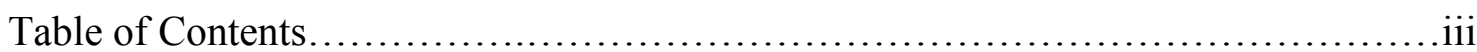

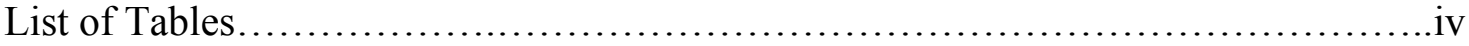

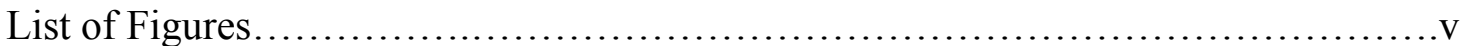

Chapter 1

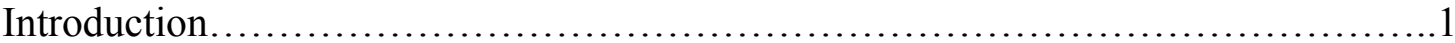

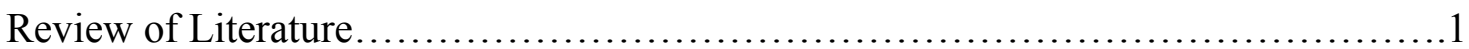

Chapter 2

Methods......................................................................11

Chapter 3

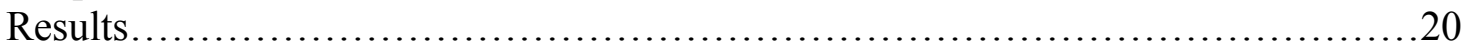

Chapter 4

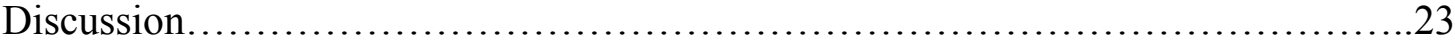

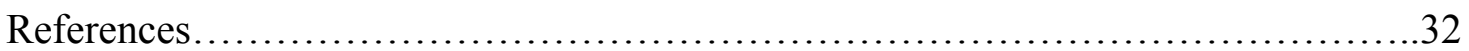

Appendices...................................................................

A. Classroom Management Checklist-Self Assessment Tool..................38

B. Self- Assessment Tool - References..............................40

C. Teacher Averages of Each Checklist Item..........................42

D. Data Collection Sheet..............................................43

E. Figures........................................................44 


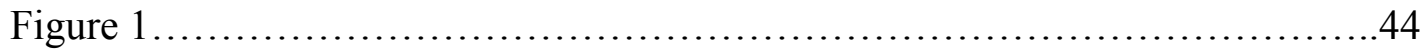
Active Supervision Across Classrooms

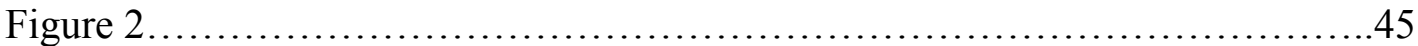

Consistent Rules Across Classrooms

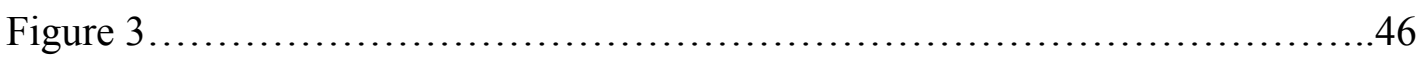
Attention Cue Across Classrooms 
Antisocial student behavior has been considered a result of teacher behaviors such as: "get tough" punitive disciplinary strategies; unclear student expectations and consequences; and lack of accommodation for individual student differences (Lewis \& Sugai, 1999). Clear classroom expectations and strong staff support that accommodates all students is essential for creating a positive learning environment (Rosenberg, 1986). For students that are receiving instruction in a juvenile correction facility, it is especially important that students are set up for success given their failures with previous educational placements. A key element to ensure that incarcerated youth successfully transition back into society is the need to be provided with appropriate educational opportunities (Gagnon, Barber, VanLoan, \& Leone, 2009). This shows that providing students with an appropriate education is essential for them to be able to better their future. Lack of formal classroom and behavior management training in teacher programs shows that it is of "low importance" and is an area where most teachers are going to need extra support and help when entering the teaching world (Acuna, 2011). In the juvenile corrections setting, extra support in this instructional process is absolutely necessary and is the reason for the study.

\section{Review of Literature}

Classroom Management: Best Practices. Recommended guidelines for ensuring student success in classrooms have been presented in the literature (Doyle, 1986). Table 1 provides a review of best practices in classroom management and their references. One important piece in the classroom is that the rules and expectations should be posted and referred back to throughout the school year (Johnson \& Stoner, 1996). In order to see 
effective student behavior, classrooms need to design and clearly communicate rules 2 and procedures (Sayeski \& Brown, 2011). When rules are not clearly posted, it may make it difficult for students to follow rules according to teacher standards. According to Positive Behavior Interventions and Supports (PBIS; Jovilette \& Nelson, 2010) each school and classroom should have three to five positively stated behavioral expectations for the students. If there are more than five expectations, then the students get overwhelmed. Having consistent and clear rules ensures that students will prevent student problem behaviors occurring due to inconsistencies. For example, unclear rules and expectations may present the opportunity for students to engage in problem behavior (as defined by the teacher), yet the student may perceive their actions as acceptable.

Another important aspect of classroom management is teaching, practicing and reinforcing the classroom rules and expectations (Johnson \& Stoner, 1996). This reinforces that students maintain knowledge of the rules throughout the entire school year. Students need to be taught the clear expectations, then practice them, and finally be reinforced for engaging in expected behaviors. This is essential, as we should not provide students with negative consequences for their actions unless we have seen them engage in the expected behaviors. A recommended practice for stimulating instruction involves providing students with high levels of engagement (Sayeski \& Brown, 2011). When students are engaged the number of students that "fall between the cracks" and are not successful in the classroom is minimized. Engagement is defined as following teacher directive; examples include completing work, looking at teacher, raising hand for questions, working with partner, etc. Students should have multiple opportunities to respond with feedback for correct and incorrect responses. Student responses provide 
instructors with information as to which students will still need further intervention. 3 Additionally, the types of individual supports can be guided by data gleaned from interactions between the teacher and the student during instructional sessions.

In an effort to increase time spent on teaching and learning in the classroom teachers should use an effective attention getting cue (Epstein, et al., 2008). An attention getting cue is a signal that all of the students will practice, know, and respond quickly to so that the next announcement can be made. The use of an attention-getting cue will increase the amount of time that can be spent teaching and decrease the amount of time trying to get students attention.

Any behavior (routine, transition, expectation) has five steps to help students understand the importance of the behavior: (a) provide a rationale, (b) explain the expected behavior, (c) model the expected behavior, (d) practice the expected behavior, and (e) monitor and provide feedback (McIntosh, Herman, Sanford, McGraw, \& Florence, 2004). These steps will reinforce the behavior at all levels so that students are clear of what is expected of them.

Teachers should also acknowledge student positive behavior four times more than the negative behavior (Cameron \& Pierce, 1994). Positive reinforcement will encourage other students to focus on the positive behaviors during class because it will be what gets them more recognition. This focus will help to minimize negative, attention-seeking behaviors in the classroom.

According to Epstein et al., (2008) transition procedures are beneficial to students and teachers alike. Transition procedures help students know what is expected thus increasing the amount of time spent engaging with instruction within the classroom, 
versus switching from one activity to another. Transitions should be viewed as one

more skill to teach, practice, and reinforce. Successful transitions are associated with (a) teaching clear expectations for student behavior; (b) establishing clear expectations for staff behavior during transitions; (c) preplanning transition implementation; (d) following transition routines consistently; and (e) providing regular and frequent acknowledgements for successful transitions (Lewis \& Sugai, 1999). Without practice of these routines, time will be spent on correcting errors within transitions thus reducing the amount of teacher time spent on instruction.

There are day-to-day routines that students will use throughout the entire school year. These routines include things like entrance and exit routines, bathroom routines, and transition routines. In order to ensure that students understand the routines early in the school year, it is important to "institute practices that 'tell' the students what is expected, 'show' them what the skill looks like, and 'practice' the skills through role plays and in-vivo situations" (Lewis \& Sugai, 1999, p. \#). If students forget the routines throughout the school year, then teachers should follow the same set of steps to reinforce and reteach the routine to their standards.

In order to limit problem behaviors in the classroom, teachers should be actively supervising by moving around the classroom and continually scanning so that they are aware of things going on in the room (DePry \& Sugai, 2002). It is more difficult to engage in problem behaviors if the teacher is constantly around the students. Physical proximity and nonverbal prompts, (e.g., pointing to the text) while the teacher is moving around the room will also help limit the problem behaviors and keep students engaged and on-task (De Pry \& Sugai, 2002). Teachers that stand and lecture at the front of the 
room, not only aren't engaging for all students, but aren't providing active

supervision to the back of the classroom. Without active supervision students may not complete work and engage in disruptive behaviors unseen by the teachers. According to McIntosh et al., (2004) interacting with students to teach behavior, pre-correct, and build positive relationships will also prevent inappropriate behavior in the classroom. The emphasis in active supervision is on moving and scanning, but interacting and building relationships will provide valuable support to teachers when establishing beneficial classroom management throughout the year.

Organizing a classroom environment in a way that allows students to efficiently access materials may increase instructional time. Instructional engaged time has shown to improve student performance so it is important to make materials orderly and easily accessible (Evertson \& Weinstein, 2006). Materials should be passed out before lessons or easily accessible to students so that they can get it independently without disrupting the class.

Teachers should spend the majority of their time and efforts on teaching and reinforcing the behaviors that they want to see in the classroom. If too much time is given to problem behaviors, then students will realize that those are good ways to get the attention of the teacher. It is important to "quickly and effectively respond to problem behaviors, while promoting expected behaviors" and without spending much time on it (Colvin, 2004).

One of the best ways to keep students engaged and on-task is to anticipate and correct behaviors before they even occur. Many schools use a proactive management approach such as PBIS (Horner \& Sugai, 2005). By engaging in preventive management 
strategies, schools will stop the majority of problem behaviors before they escalate into something unmanageable and even more disruptive (Lewis \& Sugai, 1999). Many of these approaches use positive reinforcement techniques to help strengthen the behaviors that are desired from the school. It is important that all teachers take an active role in using this system so that all students buy into using it too.

PBIS emphasizes the use of more positive feedback than negative, often referred to as 5 positives to 1 negative ( 5 to 1 ). Teachers found that the more positive reinforcement that was given throughout the school day lead to lower problem behaviors in the school (Sprague, Walker, Golly, White, Myers, \& Shannon, 2001). This is something that sounds easy, but is often lagging in the classroom. Negative comments are not always comments that are harsh it may be a comment that provides corrective feedback even when phrased in the most positive of ways. For example, a negative comment is asking, "please stop doing that behavior." Instead you should remind and ask them of the behavior that you would like to see. It is beneficial to focus on the behaviors that we would like to see in the classroom and give them the feedback versus focusing on correcting behaviors. Behaviors do indeed need to be corrected, but in a manner that is quick and places emphasis on the positive things going on in the classroom.

McIntosh et al. (2004) recommend that teachers be specific with their praise to students. The rote use of the phrase, "good job" may not mean as much to a student as "thank you for raising your hand and waiting quietly until I could get over to you." The more specific you can be towards a student, the more it will mean something and the more likely they will remember and continue to perform the desired behavior in the future. 
Students who are engaged in the classroom instruction are less likely to have behavior problems (Espin \& Yell, 1994). If the students are engaged, excited, and focused then they have less time to lose interest and engage in problem behaviors. It is the teacher's responsibility to find ways to ensure that students are fully engaged in the activities and provide activities for students that finish activities early.

Quick paced instruction leads to engaged students (Sutherland, Alder, \& Gunter, 2003). Engaged students stay focused on the task at hand and cause less issues in the classroom (Espin \& Yell, 1994). Sayeski and Brown (2011) list some techniques that help with quick paced instruction such as using response cards, choral reading, and clear communication to keep students on-task. Those techniques will help teachers check for understanding frequently and for all students at once. The techniques will also guide teachers, along with students, to stay on task and not get engaged in side conversations from individual responses.

Unclear rules and expectations, even of assignments, can contribute to the development of antisocial behavior in children and youth (Sprague et al., 2001). It is vital that all students know what is expected out of the assignment so that they work to their fullest ability. Students who do not know what is expected do not always ask for help. Sometimes these students just guess or do something completely unrelated to the assignment. Sometimes these students just guess or do something completely unrelated to the assignment. The more students on task in a classroom will decrease problem behaviors. There will not be time for students to engage in off-task behaviors if they are continually provided with learning material to be engaged in. By addressing the majority 
of students with high levels of engagement, it has been found to reduce behavioral issues in the classroom as well.

\section{Instructional Coaching on Best Practices}

Instructional coaches have been used to assist teachers in understanding and incorporating research-validated practices in their classrooms (Knight, 2004). Knight discussed how instructional coaches work best when they are able to respond to teachers' individual needs. Teachers who receive more ongoing support implement practices with higher fidelity resulting in higher student achievement in their classrooms as compared to those who did not receive the support (Kretlow \& Bartholomew, 2010). Furthermore, by using the coaching model, teachers are allowed to explore the application of new concepts within the context of their classroom (Kretlow \& Bartholomew, 2010).

Through the use of instructional coaching on evidence-based classroom management practices, teachers of adjudicated youth may help students improve their social and academic outcomes in school (Joviette \& Nelson, 2010). Cooperation between teachers is a valuable tool to help meet the needs of the students, and of the teachers. Due to the high stress nature of the juvenile justice environment, having instructional coaching support is a potentially helpful strategy that all teachers could benefit from. Incarcerated students are generally already lower achieving and high school dropouts, so we are hoping to see the coaching increase student success in the classroom. The extra support for the teachers will make it so they can have someone with whom they can talk through difficult problems. These students provide challenging behavior, and the teachers need to have solid classroom management strategies in place in order to help ensure the students success. 
The purpose of this study was to examine methods to improve the implementation of research-based classroom management practices (Lewis \& Sugai, 1999) of high school teachers working with adjudicated youth. The research questions that guided this study were: (a) Is there a functional relationship between the completion of a self-assessment of classroom procedures and improved classroom management practices by teachers? (b) Do teachers implement self-identified classroom management procedures with fidelity? (c) Do teachers improve the fidelity of implementation of procedures when provided data on their implementation of self-identified goals?

Research question A (Is there a functional relationship between improved classroom management practices and the completion of a self-assessment of classroom management procedures by teachers?) was first measured by giving teachers a selfassessment and coaching session. Then teachers were observed in the classroom and data was collected on the implementation of the procedures chosen on the self-assessment. It was hypothesized that teachers would focus on procedures and their teaching style would be impacted by the changes.

Research Question B (Do teachers implement self-identified classroom management procedures with fidelity?) was examined by observing teachers in the classroom and collecting data on whether or not the practices were being implemented correctly and with fidelity. Teachers were given feedback when they failed to implement the practices with fidelity. It was hypothesized that after the training teachers would improve their fidelity and with coaching they would sustain the implementation of procedures with fidelity. 
Question C (Do teachers improve the fidelity of implementation of procedures 10 when provided data on their implementation of self-identified goals?) was examined during coaching sessions. Teachers were provided with feedback on how well they implemented procedures and coached on how to improve their fidelity of implementation for the future. It was hypothesized that with coaching feedback and data to support, that teachers would improve their fidelity of implementation of procedures. 


\section{Setting}

The study took place in a small high school for incarcerated youth in the Pacific Northwest. The school educated female youth that lived in the facility and attended school there. The students ranged from $8^{\text {th }}$ grade all the way up to 21 year-old students that were still working to complete their high school diplomas. At the time of the study 50 students attended the school. Half of the student population (about 50\%) qualified for special education services. The majority these students were deemed eligible for special education category of an Emotional Disturbance (“Oregon Administrative Rules,” 2013).

The school was comprised of five general classrooms, a small art class, a computer lab, a college course, and a vocational program that all occurred during the school day. The study specifically took place in three of the general studies classrooms in: US History, Math, and Language Arts. Each class consisted of 15 to 20 students, depending on attendance for that day. The same students attended each class with the exception of up to 5 differing students between classrooms.

\section{Participants}

Three general education teachers agreed to participate in the study. The teachers ranged in their years of experience from 1 to 15 years; however it was the first year in a juvenile justice setting for all three teachers. Teacher A was a first-year teacher. She completed her student teaching at an inner city school with a high level of at-risk youth. She taught US History at the current school and held her teaching license in Social Studies. 
Teacher B had been teaching for 15 years. She taught in general education classrooms, performed GED tutoring, and had a year of experience with higher populations of at-risk youth. At the current school, she taught Algebra and held a teaching license in Mathematics.

The third teacher, Teacher $\mathrm{C}$, had been working in alternative settings for the majority of his 15 years of teaching. He taught Language Arts for all grade levels. His teaching license endorsements included: Language Arts, Social Studies, and English as a Second Language. Consent for participation was received by all teachers and all students' guardians prior to conducting the study.

\section{Dependent Variables}

Classroom Practices. Teachers completed a self-assessment of classroom practices that consisted of 15 items (Appendix A). Teachers rated whether each of the items were "fully in place" in their classroom (a score of 2), "partially in place" (a score of 1), or "not in place at all" (a score of 0 ).

The first item on the self-assessment tool allowed participants to assess whether they were using 5 to 1 positive to negative interactions with students in their classrooms. A negative interaction was considered anything that involved correcting a behavior in the classroom. Positive interaction was considered acknowledging desired behaviors in the classroom.

For item 2, teachers rated themselves on classroom rules and expectations. These were to be (a) posted, (b) taught directly, (c) practiced, (d) consistent, and (e) positively reinforced. Teachers were asked to put a check mark over each of the above items that they perceived were in place. 
Item 3 assessed whether an attention getting cue or rule was taught directly, practiced, and positively reinforced was item 3 on the assessment tool. As with the previous item, they were asked to put a check mark above each item they thought was in place.

Item 4 on the self-assessment tool addressed continuous active supervision across settings and activities, including moving throughout the setting and scanning. While item 5 evaluated whether minor problem behaviors were managed positively, consistently, and quickly. Participants were also asked to place a check mark over each item that they implemented in their classroom.

In items 6 and 7, multiple questions were addressed. Item 6 assessed whether transition procedures were being taught, practiced, and positively reinforced. More specifically participants were asked to look at those three areas when students were entering the classroom, returning/cleaning supplies, changing activities, and exiting the classroom.

Item 7 assessed if typical classroom routines were taught directly, practiced, and positively reinforced. Specifically this item asked about the routines for: start of the day, group work, independent seat work, obtaining materials, seeking help, and end of the day.

Item 8 examined whether necessary materials and supplies were accessible to students in an orderly fashion. This item was not entirely pertinent to the population of this study. Due to the nature of the setting, all materials were accounted for, handed out, and collected one-by-one to ensure an accurate count of all materials. This was something that teachers could think about, but that could not be changed much in this setting. 
For item 9, teachers were asked to assess themselves on whether or not

chronic behaviors were anticipated and pre-corrected. For example, if a student consistently engaged in problem behavior during a specific activity like math, did the teacher do something to prepare the student ahead of time to help reduce behavioral issues.

Item 10 asked teachers whether students were provided with activities to engage in if they completed work before others students in the class. If teachers effectively had this in place, it could eliminate time for students to cause issues and increased the amount of learning time during the class.

Item 11 asked teachers to rate if allocated instructional time involved active academic engagement with quick paced instruction. Engaging activities might keep students attention so that they did not engage in problematic behavior. Active engagement might also help maximize learning time in the classroom so that students have the most opportunity to demonstrate what they knew and learned.

Then teachers rated themselves on item 12, whether they asked clear questions and provided clear directions of assignments. The clearer assignments were for students, the higher likelihood that they would complete them, and complete them accurately.

Item 13 stated that active academic engagement results in high rates of student success $(90 \%+)$. This means that $90 \%$ of students were successfully completing assignments and understanding the material being taught in class.

Item 14 asked each of the teachers to assess their ability to actively involve all or the majority of students in a lesson (i.e. providing activities and instruction to students of varying skill levels). Instruction should be scaffolded in such a way as to meet the needs 
of all the students in the classroom. If activities were not reaching all students, then 15 students were not engaging with the content of the lesson. This could have led to offtask, disruptive behaviors.

The final item on the assessment tool (item 15) addressed whether instructional activities were linked directly to measureable short and long-term academic outcomes. This was important to make sure what students were learning was geared towards required state standards for graduation.

Teacher outcomes. Teachers were evaluated on the completion of their selfassessment tool as well as through direct observation in the classroom of the items on the tool. Specifically, direct observation for 10-minutes focused on the teachers abilities to use: (a) consistent rules, (b) an attention cue, and (c) active supervision. Consistent rules were graphed according to level of implementation of the 5 aspects of implementation (e.g., posted, taught, practiced, consistent, and reinforced). A score of $0 \%$ was provided if none of these aspects were implemented; $20 \%$ for 1 aspect; $40 \%$ for 2 aspects; $60 \%$ for 3 aspects; $80 \%$ for 4 aspects; and 100\% for all 5 aspects. In recording the attention cue, the percentage of implementation was graphed $(0 \%$ for no aspects implemented, $33 \%$ for one aspect implemented, $66 \%$ for two aspects implemented, and 100\% for all 3 aspects implemented). Teacher behaviors were recorded using a frequency count during 10minutes of direct observation for active supervision.

For this study, the use of consistent rules and an attention cue were the main variables of interest, as all three teachers selected these variables for personal improvement. When tracking data on the use of consistent rules in the classroom, 5 different criteria were observed including if rules were: (a) posted and visible to all 
students, (b) taught, (c) practiced, (d) consistent, and (e) positively reinforced. When 16 collecting data on the use of an attention cue, 3 criteria were observed to determine whether: he cue was: (a) taught, (b) practiced, and (c) positively reinforced. When monitoring whether the teacher was using consistent classroom rules, data collectors were instructed to see if the rules were posted in the classroom. If they were, then a check mark was placed over that item on the observation sheet (Appendix D). Next, if during the observations a engaged in problem behaviors, then a check mark was given if the teacher (a) reminded the student, (b) taught what was expected, and (c) asked the student to practice the behavior. Observers also provided check marks on the data sheet if (a) students performed the expectations posted in their classroom rules and (b) the teacher positively acknowledged the student's behavior. Finally, observers recorded a check mark on the data sheet when a teacher consistently reinforced the rules during the observation.

Gathering data on using an appropriate attention cue was collected using the same procedures as those for observing consistent classroom rules (above). When students responded appropriately to the attention cue, then it was assumed that it had been taught and practiced and those items received a check mark. The teacher then positively reinforced the behavior. If the students did not respond appropriately to the cue, then it should be re-taught, practiced and then reinforced in order to receive a check mark.

\section{Independent Variable}

The independent variable in this study involved teachers (a) filling out the selfassessment, (b) rating which three they wanted to focus on, and (c) holding a coaching 
session to specifically explain what teachers should be working on in the classroom

with each of these practices. When given the intervention, teachers completed the selfassessment tool to rate themselves on 15 evidence-based practices/strategies that were used in the classroom for behavior management (Appendix A). This tool took approximately 20 minutes for the teachers to complete. Once the teachers rated themselves in all categories, they were asked to select 3 from the first five strategies that they wanted to improve. They were encouraged to work on strategies from the other 10 items independently, but were not given specific coaching and feedback on those items.

The coaching session was offered individually to each teacher after they chose the items going to improve on in their classroom. The coaching session took about 15 minutes for each teacher. Anecdotal notes were taken during the session to document when the session occurred and as a reference for future coaching sessions. If a teacher's data indicated lack of improvement, then they were offered an additional coaching session to identify strategies to improve their performance of the identified skill. The second coaching session took between 5 to 10 minutes and encouraged teachers to implement the strategies they had identified.

\section{Fidelity of intervention}

The self-assessments were collected and used as a permanent product to document the intervention occurred. Each time a coaching session occurred, meeting notes were taken and signed by both participants to document that it happened.

After each meeting, an additional observer reviewed the notes to ensure that everything was covered consistently between participants. The second observer was used 
to ensure that each participant received adequate coaching, and that no participant

was favored in the process.

\section{Design}

A multiple-baseline design, across classrooms and teachers was employed to determine if there was a functional relationship between classroom practices and the completion of self-assessment of classroom management practices.

\section{Procedures}

Baseline conditions. Baseline data were recorded on the specific teaching strategies, student engagement, and problem behavior for each classroom. For all classrooms, at least 5 more days of baseline data were collected on both student and teacher outcomes. Baseline were collected prior to teacher's reviewing the selfassessment tool and receiving coaching.

Intervention Phase. Teacher A, who was the first one to receive the intervention after class on day 5, was very excited and willing to work with the feedback. She completed the self-assessment tool in 15 minutes. Directly after completing the selfassessment, a coaching session lasting 15 minutes was conducted to discuss specific steps to implementing the self-selected items in the classroom. The specific items she prioritized for improvement during coaching session were: active supervision (item 4), using consistent rules (item 2), and using an attention cue (item 3).

Teacher B received the intervention next, after class on day 7. She took 10 minutes to finish completing the self-assessment tool and also chose to specifically work on active supervision (item 4), consistent rules (item 2), and using an attention cue (item 
3) throughout the day. We held a 15-minute coaching session to discuss how to use each of these items effectively in the classroom.

Teacher $\mathrm{C}$ received the intervention last after class on day 9. He filled out the selfassessment tool in about 15 minutes and chose the same three items as Teacher A and B. The coaching session followed directly after filling out the self-assessment tool and took about 15 minutes.

Inter-observer Agreement. A second observer accompanied the researcher 42\% of the data days. Total agreement across observers was 95\%. Total agreement was calculated by dividing the total number of agreements by the total number of data opportunities and multiplying by $100 \%$. IOA data was collected on: active supervision, consistency in rules, and use of an appropriate attention cue in the classroom. Each of the self-assessment tool items were looked at for how often inter-observer agreement was found.

Inter-observer agreement ranged from $91.5 \%$ to $100 \%$ depending on the item on the tool. Item 2 received $98.1 \%$ for active supervision, Item 3 received $95.9 \%$ for consistent rules and Item 4 received $100 \%$ for attention cue. 


\section{Self-Assessment (Individual ratings)}

Each of the 3 teachers rated themselves before starting the intervention on how well they thought they implemented each of the classroom management strategies. Their ratings are below.

Teacher A. Teacher A's overall self-rating was a score of 9 out of 12 that resulted in an average of 1.5 out of 2 for each self-selected item for improvement. For Item 1 (Appendix A), positives and negatives given, and Item 5, managing behaviors, Teacher A self-rated a score of 2. For all of the additional items, 2-active supervision, 3consistent rules, and 4-attention cue used, Teacher A gave a rating of a 1. Items 2, 3, and 4 are the ones that we focus on for this study.

Teacher B. When Teacher B completed the self-assessment tool, their overall self-rating was a score of 11 ; which averages a 1.8 for each category. For Items 1positives and negatives given, 2-active supervision, 3-consistent rules, and 5-managing behaviors, Teacher B gave a rating of a 2 . For Item 4, attention cue, they rated themselves a 1.

Teacher C. When Teacher C completed the self-assessment tool, their overall self-rating was a score of 10; which averages a 1.7 for each category. For Items 1positive and negatives given, 3-consistent rules, and 5-managing behaviors, Teacher $\mathrm{C}$ gave a rating of a 2 . They rated themselves a 1 for both Items 2 -active supervision, and 4attention cue.

\section{Teacher Outcomes}


For Teacher A, there was an increase in level of supervision (item 2) after the 21 intervention and coaching session. Using consistent rules (item 3) showed a change in level and trend. A change in level was seen with the use of an effective attention cue (item 4). Teacher A received intervention after class on day 5 and initially did not see much of a change in teaching strategies. After day 7, 3 days of no real change, Teacher A received a second round of coaching. From here, she showed improvement in using consistent rules, active supervision, and using an attention cue.

When looking at the supervision levels, there was a change in level and trend after coaching sessions for Teacher B. Having consistent rules did not have an immediate effect, but there was an increase in trend. Teacher B had an increase in level and trend for the use of an effective attention cue. After the initial coaching session, after class on day 7, Teacher B improved in all areas of the study. On day 9 , the data showed that consistent rules, and having active supervision all declined so another round of coaching was used. Again, after the coaching session, all areas improved again.

There was no change in supervision levels, consistent rules, or using an effective attention cue for Teacher $\mathrm{C}$. There was not have a solid trend during baseline data collection. After the initial intervention and coaching day, after class on day 9, Teacher $\mathrm{C}$ showed improvement in all areas. The data did not increase much and leveled out, therefore not establishing a true effect. On day 12 , Teacher $\mathrm{C}$ decreased in the areas of using consistent rules, and use of an attention cue. If the study were to continue, Teacher $\mathrm{C}$ would receive another coaching session at this time to see if those areas would again increase after the coaching session. 
When looking specifically at the two areas that all three teachers chose to work on (item 3- "consistent rules", and item 4-“attention cue") it appears as though the coaching sessions helped improve all of these areas for the teachers. When looking at the before and after averages of consistent rules, all three teachers improved. For this strategy, data were collected on 5 different aspects of maintaining consistent rules and given a percentage based on how many of the 5 criteria were met. The five criteria were that the rules were posted, taught, practiced, reinforced, and consistent. Teacher A improved from an average of $24 \%$ to $52.5 \%$, Teacher B from $45.8 \%$ to $63.3 \%$ and Teacher C from $51.3 \%$ to $74.5 \%$. Again, the coaching sessions were successful in increasing teacher fidelity of this strategy in the classroom.

The other strategy that each teacher chose to focus their coaching sessions on was using an attention cue to get students to regain focus and listen. This data were collected in the same way as the consistent rules, but there were only 3 criteria being looked at. Those criteria were whether the attention cue was directly taught, practiced and positively reinforced. The data show that the coaching sessions lead to higher fidelity of this strategy being implemented in the classrooms as well. Teacher A went from no attention cue to using it $49.5 \%$ effectively, Teacher B went from $18.9 \%$ to $71.8 \%$ and Teacher C increased from $51.3 \%$ to $74.5 \%$. The coaching session was beneficial for the use of this strategy, along with using consistent rules, and active supervision. 
When looking at active supervision in the classroom, Teacher $\mathrm{A}$ and $\mathrm{C}$ rated themselves a 1, while Teacher B rated a 2. Teacher A was not accurate in her response; she did not have it fully in place. She was a stand in front and lecture type of teacher. After the intervention and discussion on why it is important to move around the classroom to supervise, Teacher A was able to at least walk around once or twice throughout the observation. Teacher B rated herself a 2 and having active supervision fully in place. She had the highest scores overall but never moved throughout the classroom more than 3 times during baseline. After the intervention she was moving throughout the classroom 3 to 5 times during the observation. Teacher $\mathrm{C}$ rated himself as partially having active supervision in place in his classroom. His classroom was set up in a ' $U$ ' shape which leads to being able to see all students while at the front of the classroom. This was different than the rows that the rest of the teachers had. Teacher C only moved around the classroom about once an observation, but was able to see, hear, and keep off-task behaviors to a minimum due to the desk set-up. After intervention, he only began moving about the classroom twice an observation, so there was not much of a change.

Teacher A rated having consistent rules only partially in place, which Teacher B and Teacher $\mathrm{C}$ each rated fully having them in place in their classroom. Teacher A was correct and only met the consistent rule guidelines with $20 \%$ before intervention. After intervention her percentage went up each couple of days, and ended at $80 \%$ applied in the classroom. Teacher B was implementing between $40 \%$ and $60 \%$ of the consistent rules during baseline. After the intervention, data was slow to change, but did end at $80 \%$ 
implemented by the final 2 days of the study. Teacher C was all over the board with 24 consistent rules. His data was increasing during baseline due to his own adjustments in teaching styles. After intervention he was implementing consistent rules with $80 \%$ to $100 \%$ for the remainder of the study.

All three teachers rated themselves as "partially in place" for using an appropriate attention cue, yet identified this as an area for improvement. Teacher A did not use an attention cue at all during baseline. After the intervention, she was effectively using an attention cue with $33 \%$ to $66 \%$ accuracy. During baseline, Teacher B used an attention cue only up to $33 \%$ of the time. After the intervention, it was implemented $66 \%$ to $100 \%$ of the time. Teacher $\mathrm{C}$ used an attention cue $33 \%$ to $66 \%$ of the time during baseline. There was only one day after intervention that Teacher $\mathrm{C}$ was able to use the attention cue $100 \%$ of the time while the rest of the days remained at $66 \%$ accuracy.

The final area that teachers were assessed on was managing problems. All three teachers gave a self-assessment that they had managing behaviors fully in place in their classroom. Teacher A had 33\% of behaviors managed effectively before intervention (with the exception of one day having 66\%) and was able to get it up to $66 \%$ after receiving the intervention. Teacher B had the exact same statistics as Teacher A in this category. Teacher $\mathrm{C}$ was able to manage problems in the classroom $100 \%$ of the time on 6 out of 9 baseline days. After the intervention, the amount of $100 \%$ effective behavior management was 3 out of 4 data days.

Each of the teachers received a second coaching session during the study. The coaching session was decided based on the fall of data on the previous day in their classroom. It was merely a reminder and check-in to make sure that each teacher knew 
what was expected. All of the teachers knew, but admitted that they did not

remember to focus on their checklist items during that day. The day after the coaching session, each of the teachers increased their data scores again. This shows that check-ins and having a coach helps to reinforce strategies (Kretlow \& Bartholomew, 2010) to continue to use the learned strategies with fidelity in the future. During these coaching sessions, the teachers were not learning something new, but checking-in with a coach and getting positive reinforcement and reminders to use strategies that are proven to help with classroom management.

\section{Research Questions}

(a) Is there a functional relationship between teacher implementation of classroom management procedures and student academic engagement? Student academic engagement was already higher than expected when going into this study. It was above $80 \%$ for the majority of baseline collection and after intervention. The implementation of the procedures and strategies helped to keep academic engagement above $80 \%$, but did not raise the percentage significantly.

(b) Do teachers implement self-identified classroom management procedures with fidelity? With coaching, teachers were able to implement classroom management procedures with fidelity. When they forgot to continue to implement them, a second coaching session was offered that helped them to review and implement strategies effectively the next day. If this study were to continue throughout the entire year, strategies would become more natural for teachers after multiple coaching sessions and feedback of how the procedures are working for their classroom. 
(c) Do teachers improve the fidelity of implementation of procedures when

provided data on their implementation of self-identified goals? During the second coaching session, teachers were able to see that their data had dropped when they stopped using the strategies with fidelity in their classroom. After the second coaching session, each teacher improved in their fidelity and was able to continue to implement the strategies effectively.

\section{Social Validity}

When discussing with teachers after the study, all found at least some of the study to be helpful. Teacher A took away a lot of ideas and "can't wait to try more in her classroom." She was very appreciative of the feedback and having someone else be able to focus on what was going on in her classroom. She stated that she really enjoyed the coaching sessions and time to brainstorm solutions with another teacher. She would definitely participate in expansions on the study, if it were to continue, so that she can grow and gain more tools for the future.

When talking with Teacher B, she found the feedback helpful, but wasn't sure that the strategies were something she would continue to use. She understood that the data showed the strategies were working, but she did not feel comfortable using the strategies and thought it might be hard to remember to implement them in the future. She did think that the coaching sessions would be a valuable tool for new teachers to have when they enter the teaching world. She would recommend the study to newer teachers, but is not sure if it helped her enough to participate again.

"I enjoyed the feedback and new suggestions of how to deal with some of the behaviors in my classroom," said Teacher C when discussing his opinions on the study. 
He liked that when looking at the behaviors of 2 or 3 students and finding a strategy

to help them stay on task, it helped 5 others that he didn't realize needed it. The strategies that were implemented were ones that applied to all students, not just the more severe behaviors. He also enjoyed the coaching sessions because the sessions were a chance to bring up issues that he wanted to discuss, along with look at the data and see if his implementations were having an effect. Overall, he would participate in the study again and recommend it to other teachers.

\section{Data Days and Variables}

There were some data days that stuck out as "odd" while conducting the study. On day 10, Teacher A had no issues in the classroom, students were on-task, and everyone was $95 \%$ on task. This day lead to a higher data spike in consistent rules being followed because the rules were being followed. There was also a drop in data on day 14, 3 data collection day after intervention, which led to an additional coaching session. Teacher A admitted that she was not feeling well and did not remember to focus on any of the strategies that we had discussed. The following data day reflected that she was feeling better and the data began to go back to where it was at previously.

Teacher B had an increase in all of her areas. There were no days that stood out on the 3 items that we observed. She had a few behavioral challenges (a particular quadrant that we observed) that caused a drop in the two items that we didn't include in the study (Item 1 and 5). Overall, the rest of her strategies had increased and would have showed better if those behavioral challenges had been addressed quicker and removed.

There were a few variables for Teacher $\mathrm{C}$ that affected the data. The first issue was that on day 5 there was an incident in the facility that kept the students from coming 
to Teacher C's class on that day. The students were able to attend their other classes 28 that morning, but not his. Teacher $\mathrm{C}$ had an outlier day on day 11 where his attention cue was not working, and rules were only $40 \%$ consistent. This was during baseline, so the reasoning behind the lower data is uncertain. The final day of the study was leading into a week, long break for students. This showed in the data with Teacher $\mathrm{C}$ with consistent rules, and attention cue dropping from their previous $100 \%$ achievement on the previous day. The only thing that explains why the data dropped was the fact that the students and teacher were both focused on the week off and completing things before time was up.

\section{Limitations to the Study}

The study began with 4 classroom teachers but one was unable to participate in the study shortly after the intervention was given. This limited the amount of classrooms we were able to assess and monitor. Having only 3 participants did not allow for an accurate portrayal of whether the coaching sessions and data were having an effect or not.

The other limitation to the study was the engagement level of the students. When deciding whether this would be a useful study, the students in this facility rarely participated, often acted out, and were disrespectful in the school environment. Once we began the study, however, they turned around and were generally active classroom participants and had minimal issues in the classroom. This could have been due to the observer effect where the students behaved differently with someone else in the room. The students all know that the researcher and inter-observer are involved in the school, and were excited to be a part of the study. This could have played a role in their behavior when they knew they were being watched, even though they knew the researchers were focused on the teacher and not them. It is also believed that the observer effect had an 
impact on the teacher behavior. There was anecdotal evidence of classroom issues

while the study was going on, but did not coincide with study related observational times. The use of other techniques such as video recording or one way mirrors could have more objectively tracked student behavior, and thus could get a better representation of student and teacher behavior in the classroom.

Originally teachers were observed using 5 positives to 1 negative feedback comments (Item 1). Some teachers were unclear of what this meant, even with coaching, and did not use true positive feedback. This made the results random and not fit with the study. In the future, this is an area that could specifically be assessed in a setting similar to this one. I believe that it is an important strategy for teachers to use, and especially with high-risk youth.

We also didn't use Item 5 (addressing behavioral challenges) because it could have been an entire study on it's own. Teachers had a harder time working on this item, as the behaviors were generally good during this study. When there were challenges, teachers were inconsistent on how to deal with the issues. There was too much coaching to go along with the other items, so we decided not to use this item. It would be a good study in the future.

Due to the nature of the setting, there were days when data could not be collected as planned due to OAKS state testing, facility lock-downs, teachers out sick, and guest teachers and assemblies coming into the facility. This limited the amount of days that data could be collected; therefore it was found that there were minimal data days to complete the study before summer breaks and vacations arose and disrupted the data process further. 
There was an "outside discipline" that could have contributed to better student 30 behavior. A different program previously ran the school and when the study began the students were still adjusting to the new school program. They tested boundaries and fought the school briefly but realized that the Oregon Youth Authority staff (the correctional staff) was on the same team as the school. This meant that getting in trouble in school lead to future consequences on the living unit later that evening as well. This added consequence could have an effect on why students had better behavior than expected.

The final area that would have been helpful to gather data on would have been the grades and amount of work actually completed by the students. Students were tracked on being engaged in the classroom but it is not certain whether the engagement translated into their grades and work.

Implications. This study could impact other teachers by showing that classroom management strategies have positive effects on all students, even those students that are considered an extreme challenge to classroom management. This study serves as a pilot study to being observing and testing other classroom management strategies more specifically in such secure settings. It provides teachers in these settings with ideas and guidance to implement such strategies in their own classrooms. Often, students within the correctional setting are tagged with the stigma that they are not capable of learning. The youth and young adults within the correctional system are students who can have the potential to succeed with their educational endeavors. It is the responsibility of the teacher to foster their growth and educate these students. While the correctional classroom can be difficult to manage, this study has demonstrated that with coaching and 
improved instructional techniques students can succeed and excel with their educational goals.

\section{Future Directions}

Expansions. An expansion for this study should to include more participants. The study started with four participants, but one dropped out right after the intervention leaving only three participants left. More participants would mean more data to collect and review to see if the strategies are working.

Another way to expand the study would be to gather data longer after the intervention. Due the structure of the setting, we did not gather as many data days as could be useful. The study could be more successful if it was over the course of an entire school year to really show the teachers getting adequate coaching sessions (versus two in

this study), and by giving teachers time to try the different strategies in different ways so that they would be truly beneficial to them.

It would also be interesting to compare the data between this setting (all female) and an all male, youth correctional facility. This could include another school that is similar, but all male, to expand the data collection. Possible strategies that work well with females, may not work well with males, and vise versa. By adding an all male facility, it would strengthen findings to show that they work across similar settings. 
Acuna, M. (2011). Better choices: Evaluating the effectiveness of behavior management programs. (Unpublished doctoral dissertation). Dominican University of California, San Rafael, CA.

Barbetta, P.M., Heward,W L, Bradley, D M, \& Miller, A D. (1994). Effects of immediate and delayed error correction on the acquisition and maintenance of sight words by students with developmental disabilities. Journal of Applied Behavior Analysis, 27, 177-178. doi:10.1901/jaba.1994.27-177

Brophy, J. E.(1983). Classroom Organization and Management. The Elementary School Journal 83 (4), 265-285.

Cameron, J. \& Pierce, W. (1994). Reinforcement, Reward, and Intrinsic Motivation: A meta-analysis. Review of Educational Research 64(3), 363-423. doi:10.3102/00346543064003363

Carnine, D.W. (1976). Effects of two teacher-presentation rates on off task behavior, answering correctly, and participation. Journal of Applied Behavior Analysis, 9, 199-206. doi:10.1901/jaba.1976.9-199

Christle, C. A., \& Schuster, J. W. (2003). The effects of using response cards on student participation, academic achievement, and on-task behavior during whole-class, math. doi:10.1023/A:1025577410113

Colvin, G. (2004). Managing the cycle of acting-out behavior in the classroom. Eugene, OR: Behavior Associates.

Colvin, G., Ainge, D. \& Nelson, R. (1997). How to defuse confrontation. Teaching Exceptional Children, 47-51. 
Colvin, G., Sugai, G., \& Patching, W. (1993). Pre-correction: An instructional strategy for managing predictable behavior problems. Intervention in School and Clinic, 28, 143-150.

De Pry, R.L., \& Sugai, G. (2002). The effect of active supervision and precorrection on minor behavioral incidents in a sixth grade general education classroom. Journal of Behavioral Education, 11, 255-264. doi:10.1023/A:1021162906622

Doyle, W. (1986). Classroom organization and management. In M. Wittrock, Handbook of research on teaching. (3rd ed.) (pp. 392-431). New York: Macmillan.

Espin, C., \& Yell, M. (1994). Critical indicators of effective teaching for preservice teachers: relationship between teaching behaviors and ratings of effectiveness. Teacher Education and Special Education, 17(3), 154-169. doi: $10.1177 / 088840649401700303$

Epstein, M., Atkins, M., Cullinan, D., Kutash, K., and Weaver, R. (2008). Reducing Behavior Problems in the Elementary School Classroom: A Practice Guide (NCEE \#2008-012). Washington, DC: National Center for Education Evaluation and Regional Assistance, Institute of Education Sciences, U.S. Department of Education. Retrieved from http://ies.ed.gov/ncee/wwc/publications/practiceguides.

Evertson, C. \& Weinstein, C. (Eds.) (2006). Handbook of classroom management: Research, practice, \& contemporary issues. Philadelphia: Lawrence Erlbaum Gagnon, J., Barber, B., VanLoan, C., and Leone, P. (2009). Juvenile correctional schools: characteristics and approaches to curriculum. Education and Treatment of Children, 32(4), 673-696. doi: 10.1353/etc.0.0068 
Johnson, T., and Stoner, G. (1996). Demonstrating the experimenting society model 34 with classwide behavior management interventions. School Psychology Review, 25(2), 199-214.

Jovilette, K. and Nelson, C. (2010). Adapting positive behavioral interventions and supports for secure juvenile justice settings: improving facility-wide behavior. Behavioral Disorders, 36(1), 28-42.

Knight, J. (2004). 5 key points to building a coaching program. Journal of Staff Development, 28(1), 26-31.

Knight, J. (2004). Instructional coaches make progress through partnership. Journal of Staff Development, 25(2), 32-27.

Kretlow, A. and Bartholomew, C. (2010). Using coaching to improve the fidelity of evidence-based practices: a review of studies. Teacher Education and Special Education, 33(4), 279-299. doi: 10.1177/0888406410371643

Lambert, M.C., Cartledge, G., Lo, Y., \&Heward, W.L. (2006). Effects of response cards on disruptive behavior and academic responding during math lessons by fourth grade urban students. Journal of Positive Behavior Interventions, 8, 88-99. doi:10.1177/10983007060080020701

Lewis, T. and Sugai, G. (1999). Effective behavior support: a systems approach to proactive schoolwide management. Focus on Exceptional Children, 31(6), 1 24.

McAllister, L.W., Stachowiak, J.G. Baer, D.M. Conderman, L. (1969). The application of operant conditioning techniques in a secondary school classroom. Journal of Applied Behavior Analysis ,2(4), 277-285. doi:10.1901/jaba.1969.2-277 
McIntosh, K., Herman, K., Sanford, A., McGraw, K., and Florence, K. (2004).

Teaching

transitions: techniques for promoting success between lessons. TEACHING Exceptional Children, 33(1), 32-38.

Oregon administrative rules. (2013). Retrieved April 29, 2013, from http://www.ode.state.or.us/search/page/?id=1373

Rosenberg, M. S. (1986). Maximizing the effectiveness of structured classroom management programs: Implementing rule-review procedures with disruptive and distractible students. Behavior Disorders, 11(4), 239-248.

Rosenshine, B. (1980). How time is spent in elementary classrooms. In C. Denham \& A. Lieberman (Eds.). Time to learn (pp. 107-126). Washington, DC: National Institute of Education.

Sayeski, K. and Brown, M. (2011). Developing a classroom management plan using a tiered approach. TEACHING Exceptional Children, 44(1), 8-17.

Sharpe, T., Brown, M., \& Crider, K. (1995). The effects of a sportsmanship curriculum intervention on generalized positive social behavior or urban elementary school students. Journal of Applied Behavior Analysis, 28(4), 401- 416. doi:10.1901/jaba.1995.28-401

Sprague, J., Walker, H., Golly, A., White, K., Myers, D., and Shannon, T. (2001). Translating research into effective practice: the effects of a universal staff and student intervention on indicators of discipline and school safety. Education and Treatment of Children, 24(4), 495-511. 
Sugai, G. \& Colvin, G. (2001). Classroom Management Practices Self-Assessment. 36 University of Oregon.

Sugai, G., \& Horner, R. H. (2002). The evolution of discipline practices: School-wide positive behavior supports. Child and Family Behavior Therapy, 24, 23-50. doi:10.1300/J019v24n01_03

Sutherland, K.S., Alder, N., \& Gunter, P.L. (2003). The effect of varying rates of opportunities to respond to academic requests on the behavior of students with EBD. Journal of Emotional and Behavioral Disorders, 11, 239-248. doi:10.1177/10634266030110040501

Sutherland, K.S., \& Wehby, J.H., (2001). The effect of self-evaluation on teaching behavior in classrooms for students with emotional and behavioral disorders. Journal of Special Education, 35(3), 2-8. doi:10.1177/002246690103500306

Walker, H. M., Ramsey, E., \& Gresham, F. M. (2004). Antisocial behavior in school: Evidence- based practices (2nd ed.). Pacific Grove, CA: Brooks/Cole.

West, R. P., \& Sloane, H. N. (1986). Teacher presentation rate and point delivery rate: Effects on classroom disruption, performance, accuracy, and response rate. Behavior Modification, 10(3), 267- 286. doi:10.1177/01454455860103001 
Appendix A

Table 1 - Self-Assessment Tool

Appendix B

Table 2 - References

Appendix C

Table 3 - Teacher Self-Assessment Averages

Appendix D

Table 4 - Data Collection Sheet

Appendix E

Figure 1 - Active Supervision

Appendix F

Figure 2 - Consistent Rules

Appendix G

Figure 3 - Attention Cue 
Table 1

Classroom Management Checklist - Self Assessment Tool

Teacher

Grade/Subject

School

\begin{tabular}{|c|c|c|c|c|c|c|}
\hline & Place S1 & & & I Practic & & \\
\hline $\begin{array}{c}\text { Full } \\
\text { (2) }\end{array}$ & $\begin{array}{c}\text { Partia } \\
1 \\
\text { (1) }\end{array}$ & $\begin{array}{c}\text { Not } \\
\text { (0) }\end{array}$ & & & & \\
\hline & & & & Manage & & \\
\hline & & & $\begin{array}{l}\text { 1. } 5 \text { to } 1 \text { po } \\
\text { below). }\end{array}$ & ve intera & bse & \\
\hline & & & \# Positive & \# Nega & & \\
\hline & & & $\begin{array}{l}\text { 2. Classroo } \\
\text { directly } \\
\text { reinfor }\end{array}$ & $\begin{array}{l}\text { ctations } \\
\text { isistent, }\end{array}$ & ly & \\
\hline & & & $\begin{array}{l}\text { 3. Attentiol } \\
\text { \& posit }\end{array}$ & $\begin{array}{l}\text { le taught } \\
\text { d. }\end{array}$ & prac & \\
\hline & & & $\begin{array}{l}\text { 4. Continu } \\
\text { activiti } \\
\text { scannir }\end{array}$ & $\begin{array}{l}\text { vision ac } \\
\text { oving thr }\end{array}$ & $\begin{array}{l}\text { ngs } \\
\text { ettir }\end{array}$ & \\
\hline & & & $\begin{array}{l}\text { 5. Minor pi } \\
\text { consist }\end{array}$ & rs manag & rely, & \\
\hline & & & $\begin{array}{l}\text { 6. Efficien } \\
\text { positiv } \\
\text { a. Ente } \\
\text { b. Retu } \\
\text { c. Cha } \\
\text { d. Exit }\end{array}$ & supplies & $\begin{array}{l}\text { ctic } \\
\text { Y } \\
\text { Y } \\
\text { Y } \\
\text { Y }\end{array}$ & $\begin{array}{l}\& \\
N \\
N \\
N \\
N\end{array}$ \\
\hline & & & $\begin{array}{l}\text { 7. Typical } \\
\text { \& posit } \\
\text { a. Star } \\
\text { b. Gro } \\
\text { c. Inde } \\
\text { e. Obt }\end{array}$ & $\begin{array}{l}\text { nes taugl } \\
\text { lork }\end{array}$ & $\begin{array}{l}\text { pre } \\
\mathrm{Y} \\
\mathrm{Y} \\
\mathrm{Y} \\
\mathrm{Y}\end{array}$ & $\begin{array}{c}\text { ced } \\
\mathrm{N} \\
\mathrm{N} \\
\mathrm{N} \\
\mathrm{N}\end{array}$ \\
\hline
\end{tabular}




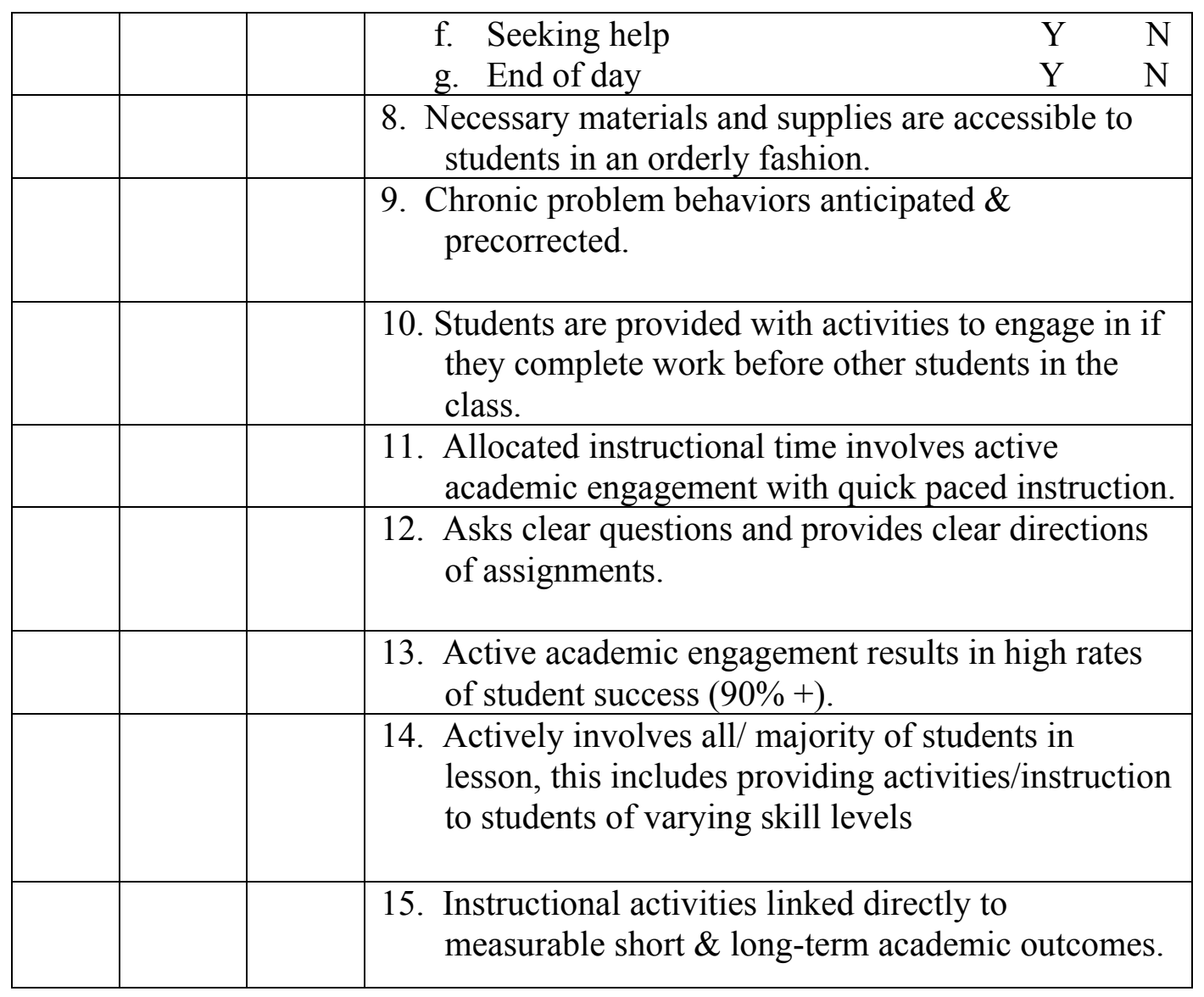

Of the first five items on the checklist, the three areas that I would like to improve in my classroom are:

1.

2.

3.

Adapted by C. Borgmeier from Sugai \& Colvin, 11/29/01 
Self Assessment Tool - References

\section{Table 2}

\begin{tabular}{|c|c|}
\hline $\begin{array}{l}\text { Rate the extent that the following classroom } \\
\text { management practices are in place in your classroom. }\end{array}$ & References \\
\hline $\begin{array}{l}\text { 1. I acknowledge student positive behavior at least } 4 \\
\text { times more often than I acknowledge student problem } \\
\text { behavior. }\end{array}$ & $\begin{array}{l}\text { Cameron \& Pierce, } \\
1994\end{array}$ \\
\hline $\begin{array}{l}\text { 2. Classroom rules \& expectations are taught, practiced } \\
\& \text { positively reinforced. }\end{array}$ & $\begin{array}{l}\text { Johnson, \& Stoner, } \\
1996 \\
\text { Sharpe, Brown, \& } \\
\text { Crider, 1995 } \\
\text { Rosenberg, } 1986\end{array}$ \\
\hline $\begin{array}{l}\text { Rate the extent the following transition procedures } \\
\text { are taught, practiced \& positively reinforced in your } \\
\text { classroom. }\end{array}$ & \multirow{13}{*}{$\begin{array}{l}\text { Epstein et al., } 2008 \\
\text { Horner et al., } 2001 \\
\text { Sugai, Hagan-Burke, } \\
\quad \& \text { Lewis-Palmer, } \\
2004 \\
\text { Sugai \& Horner, } \\
2002 \\
\text { Doyle (1986) } \\
\text { Rosenshine (1980). }\end{array}$} \\
\hline 3. $\quad$ Entering the Classroom & \\
\hline 4. $\quad$ Lining up & \\
\hline 5. Changing between activities & \\
\hline 6. $\quad$ Exiting the Classroom & \\
\hline $\begin{array}{l}\text { Rate the extent the following classroom routines are } \\
\text { taught, practiced \& positively reinforced in your } \\
\text { classroom. }\end{array}$ & \\
\hline 7. Start of the day / Beginning class & \\
\hline 8. Group work & \\
\hline 9. Independent seat work & \\
\hline 10. Obtaining materials & \\
\hline 11. Seeking assistance/help & \\
\hline 12. End of day/ End of class & \\
\hline $\begin{array}{l}\text { 13. Attention getting cue/rule taught directly, practiced } \\
\& \text { positively reinforced }\end{array}$ & \\
\hline \multicolumn{2}{|c|}{$\begin{array}{l}\text { Rate the extent that the following classroom and instructional management } \\
\text { practices are in place in your classroom. }\end{array}$} \\
\hline $\begin{array}{l}\text { 14. Continuous active supervision across settings \& } \\
\text { activities, including moving throughout setting \& } \\
\text { scanning }\end{array}$ & $\begin{array}{l}\text { De Pry \& Sugai, } \\
2002\end{array}$ \\
\hline $\begin{array}{l}\text { 15. Desks/room arranged so that all students are easily } \\
\text { accessible by the teacher }\end{array}$ & \multirow{2}{*}{$\begin{array}{l}\text { Brophy, 1983 } \\
\text { Colvin, Sugai \& } \\
\text { Patching, 1993 } \\
\text { Evertson \& } \\
\quad \text { Weinstein, } 2006 \\
\end{array}$} \\
\hline $\begin{array}{l}\text { 16. Necessary materials and supplies are accessible to } \\
\text { students in an orderly fashion }\end{array}$ & \\
\hline $\begin{array}{l}\text { 17. Minor problem behaviors are managed positively, } \\
\text { consistently \& quickly }\end{array}$ & $\begin{array}{l}\text { McAllister, } \\
\text { Stachowiak, Baer, \& }\end{array}$ \\
\hline
\end{tabular}




\begin{tabular}{|c|c|}
\hline & $\begin{array}{l}\text { Conderman, } 1969 \\
\text { Barbetta, Heward, } \\
\text { Bradley, \& Miller, } \\
1994 \\
\text { Colvin, 2004 } \\
\text { Colvin, Ainge \& } \\
\text { Nelson, 1997 } \\
\text { Colvin and Sugai, } \\
\text { 1989 Nelson, } 1996 \\
\text { Walker, 1995 } \\
\text { Walker et al., } 1995 \\
\text { Walker, Ramsey \& } \\
\text { Gresham, 2004 }\end{array}$ \\
\hline $\begin{array}{l}\text { 18. Chronic problem behaviors are anticipated and } \\
\text { precorrected }\end{array}$ & $\begin{array}{l}\text { Colvin, Ainge \& } \\
\text { Nelson, } 1997\end{array}$ \\
\hline \multicolumn{2}{|l|}{$\begin{array}{l}\text { 19. Students are provided with activities to engage in if } \\
\text { they complete work before other students in the class }\end{array}$} \\
\hline $\begin{array}{l}\text { 20. Majority of time allocated } \& \text { scheduled for } \\
\text { instruction }\end{array}$ & $\begin{array}{l}\text { Carnine, 1976; } \\
\text { Sutherland, Alder \& } \\
\text { Gunter, } 2003\end{array}$ \\
\hline $\begin{array}{l}\text { 21. Allocated instructional time involves active } \\
\text { academic engagement with quick paced instruction }\end{array}$ & $\begin{array}{l}\text { Sutherland, Alder \& } \\
\text { Gunter, } 2003 \\
\text { West \& Sloane, } 1986\end{array}$ \\
\hline \multicolumn{2}{|l|}{$\begin{array}{l}\text { 22. Ask clear questions and provides clear directions for } \\
\text { assignments }\end{array}$} \\
\hline $\begin{array}{l}\text { 23. Active academic engagement results in high rates of } \\
\text { student success }\left(90 \%^{+}\right)\end{array}$ & Espin \& Yell, 1994 \\
\hline $\begin{array}{l}\text { 24. Actively involves all/majority of students in lessons, } \\
\text { this includes providing activities/instructions to } \\
\text { students of varying skill levels }\end{array}$ & $\begin{array}{l}\text { Christle \& Schuster, } \\
2003 \\
\text { Lambert, Cartledge, } \\
\text { Heward, \& Lo, } 2006 \\
\text { Godfrey, Grisham- } \\
\text { Brown, \& Schuster, } \\
2003 \\
\text { Wehby, Symons, } \\
\text { Canale \& Go, 1995; } \\
\text { Gickling \& } \\
\text { Armstrong, } 1978 \\
\text { Sutherland \& Wehby, } \\
2001\end{array}$ \\
\hline $\begin{array}{l}\text { 25. Instructional activities linked directly to measurable } \\
\text { short \& long term academic outcomes }\end{array}$ & \\
\hline
\end{tabular}


Appendix A

Table 3

\section{Teacher Averages of Each Checklist Item}

Teacher A Teacher B Teacher C

Before

intervention

Engagement

Problem Behavior

Positive Feedback

Negative

Feedback

Active

Supervision

Consistent Rules

Attention Cue

Manage

Behaviors

After

Intervention

Engagement

Problem Behavior

Positive Feedback

84.8

15.2

2

83.7

92.2

16.3

7.8

2.3

2.6

3.4

2.3

1.8

0

2.3

1.2

24

45.8

57.8

0

18.9

51.3

39.6

37.8

88.7

Negative

Feedback

Active

Supervision

Consistent Rules

88.5

87.7

90

11.5

12.3

10

4.6

4.7

4.3

2.8

2.7

2.3

Attention Cue

Manage

Behaviors

3.8

1.8

52.5

63.3

85

49.5

71.8

74.5

66

66

91.5 
Appendix D

Table 4

Data Collection

\begin{tabular}{|l|l|l|l|l|l|l|l|l|l|l|l|l|l|l|l|}
\hline 10 & 20 & 30 & 40 & 50 & 60 & 70 & 80 & 90 & 100 & 110 & 120 & 130 & 140 & 150 \\
\hline & & & & & & & & & & & & & & \\
\hline & & & & & & & & & & & & & & \\
\hline
\end{tabular}

\begin{tabular}{|l|l|l|l|l|l|l|l|l|l|l|l|l|l|l|}
\hline 10 & 20 & 30 & 40 & 50 & 60 & 70 & 80 & 90 & 100 & 110 & 120 & 130 & 140 & 150 \\
\hline & & & & & & & & & & & & & & \\
\hline & & & & & & & & & & & & & & \\
\hline
\end{tabular}

\begin{tabular}{|l|l|l|l|l|l|l|l|l|l|l|l|l|l|l|}
\hline 10 & 20 & 30 & 40 & 50 & 60 & 70 & 80 & 90 & 100 & 110 & 120 & 130 & 140 & 150 \\
\hline & & & & & & & & & & & & & & \\
\hline & & & & & & & & & & & & & & \\
\hline
\end{tabular}

\begin{tabular}{|l|l|l|l|l|l|l|l|l|l|l|l|l|l|l|}
\hline 10 & 20 & 30 & 40 & 50 & 60 & 70 & 80 & 90 & 100 & 110 & 120 & 130 & 140 & 150 \\
\hline & & & & & & & & & & & & & & \\
\hline & & & & & & & & & & & & & & \\
\hline
\end{tabular}

\begin{tabular}{|l|l|l|}
\hline Positives & Negatives & Stpervision \\
\hline & & \\
& & \\
\hline
\end{tabular}

Consistent Rules (posted, taught, practiced, reinforced, consistent)

Attention Cue (taught, practiced, reinforced)

Manage Behaviors (positively, consistently, quickly)

Date

Teacher

BASELINE: YES or NO

NOTES: 
Appendix B

Figure 1

Active Supervision

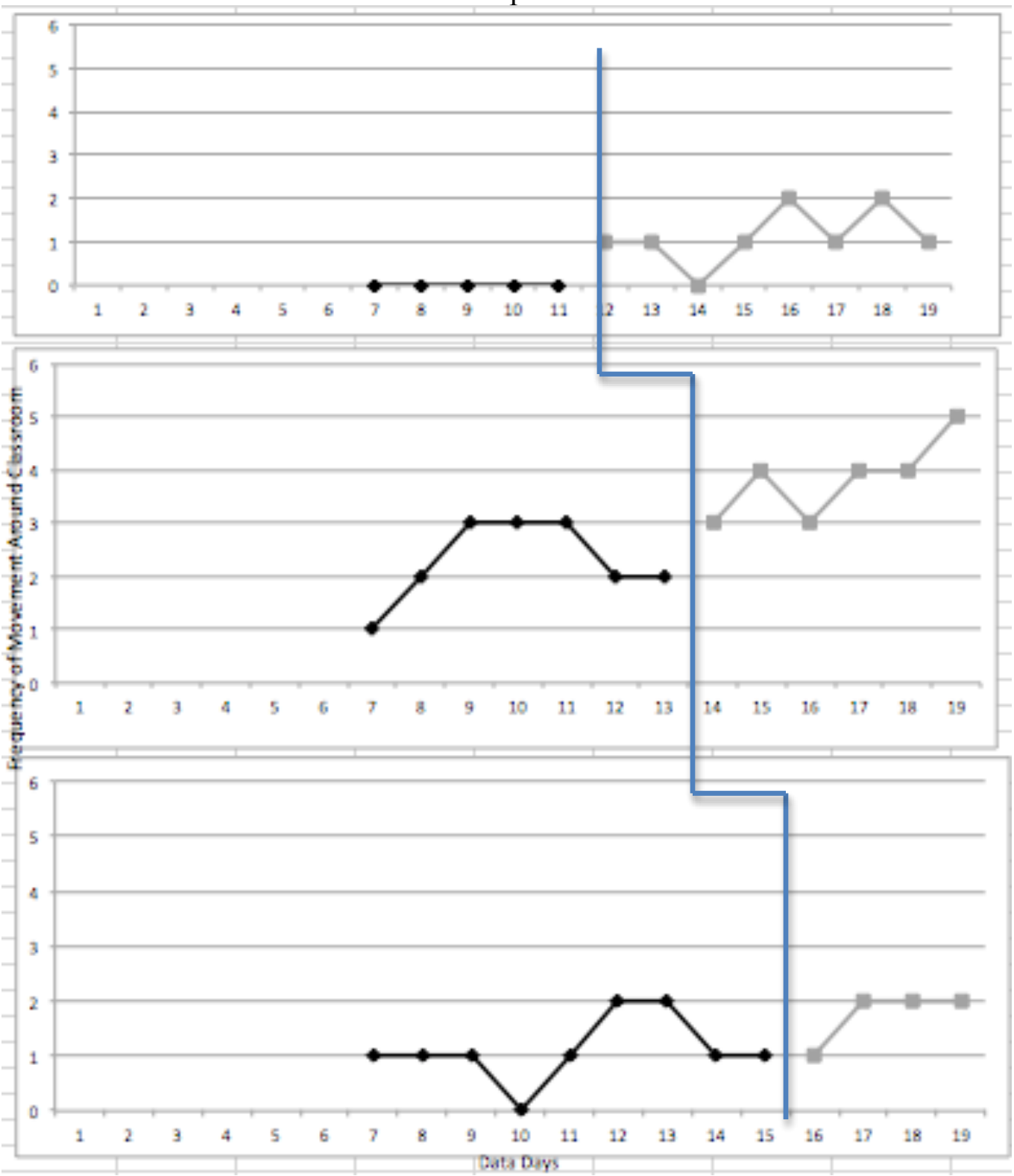


Figure 2

Consistent Rules

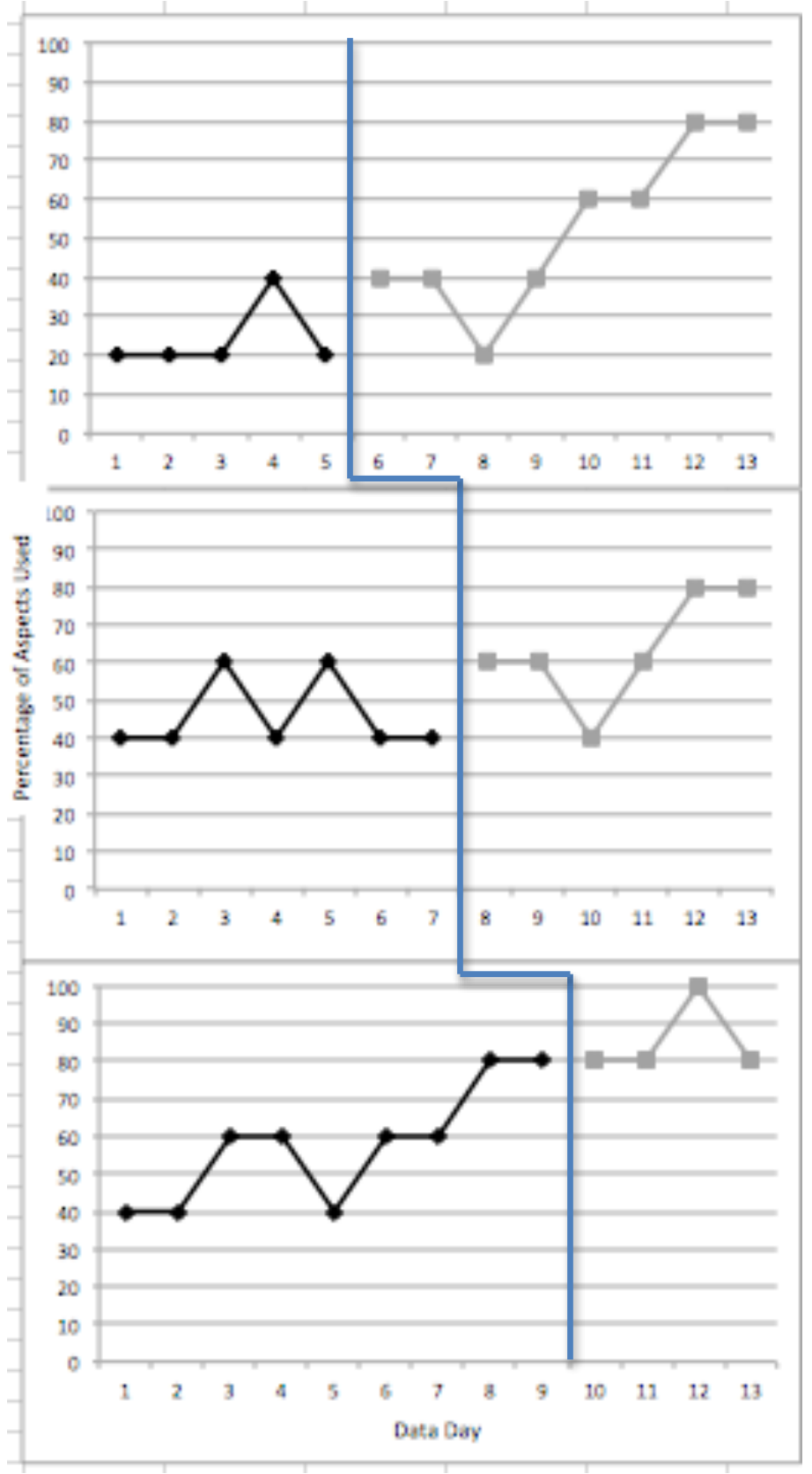


Table 3

Attention Cue

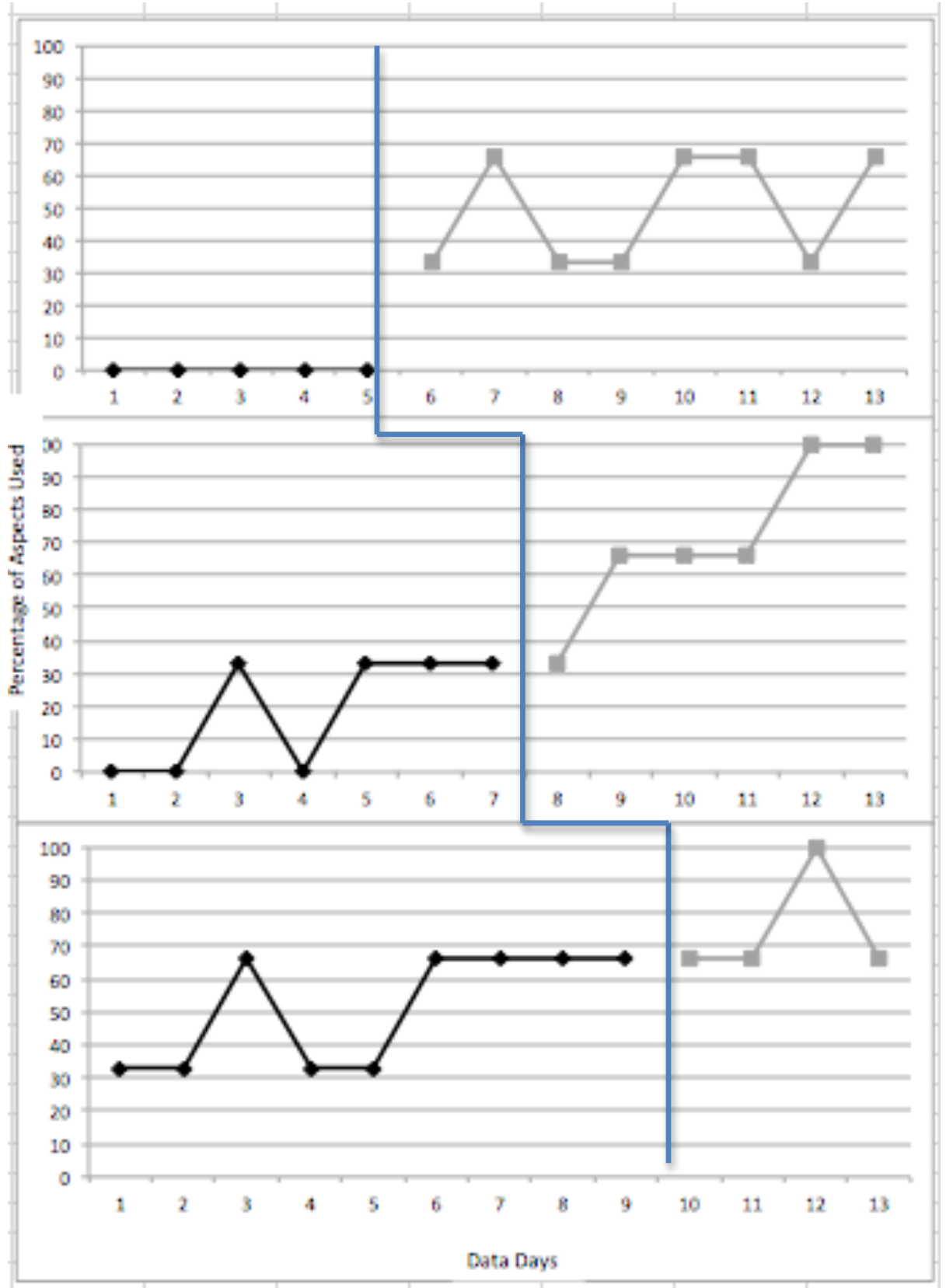

